\title{
A rendészeti környezetben elkövetett korrupciós büncselekmények felderítésének gyakorlati sajátosságai
}

\section{Practical features of detecting corruption crimes committed in police work environment}

\begin{abstract}
Absztrakt
A rendőri korrupció elleni fellépés kiemelt fontosságú speciális jellemzői és következményei miatt. A gyakorlatban a rendőri korrupciós büncselekmények felderítése, nyomozása több ok miatt is rendkívül nehéz és sokszor nem eredményes. Ennek ellenére nem követhető az a gyakorlat, mely szerint a kötelességszegéssel elkövetett hivatali vesztegetés elfogadása büncselekmény helyett egy jóval enyhébb, de könnyebben bizonyítható deliktum, a kötelességszegés szolgálatban büncselekmény miatt történik meg a gyanúsítás, a vádemelés és végül az ítélkezés is.
\end{abstract}

Kulcsszavak: korrupció, rendőrség, hivatali vesztegetés elfogadása, kötelességszegés szolgálatban

\begin{abstract}
Action against police corruption is top priority because of its special features and consequences. Detectioning and investigation of police corruption offenses in practice are extremely hard and often not effective for several reasons. However, it is not allowed to follow the practice that authorities investigate, arraign, judge the act as military crime - which has received milder punishment -, instead of a corruption crime, just because it can be proved easier.
\end{abstract}

Keywords: corruption, police, accepting official bribery, military crime 
,- Nehéz dolog - tünödött ö hangosan -

Mindenik nehéz. Elfogadni is nehéz, el nem fogadni is nehéz..."

(Móricz Zsigmond: Rokonok, 1932)

\section{Bevezetés}

Az utóbbi évtizedekben a korrupció elleni fellépés valamennyi fejlett társadalomban kiemelt feladat, hiszen megállapították, hogy a korrupció egyenesen világjelenséggé vált. (Kránitz, 1986, 264.) A nemzetközi szervezetek, a szakemberek, a felelős politikusok és a jogalkotók - ahogy Báger Gusztáv megállapítja - egyaránt felismerték a korrupció egyre nagyobb mértékü elterjedését, a jelenség problémájának nemzetközi fontosságát. Ennek következtében prioritássá vált a korrupció elleni nemzetközi egyezmények és konvenciók, az irányelvek, javaslatok és deklarációk megalkotása. E tekintetben ki kell emelni az INTOSAI ${ }^{1}$, az $\mathrm{OECD}^{2}$, az ENSZ, az Európa Tanács és az Európai Unió tevékenységét. (Báger, 2012,67 .) Továbbá azt is, hogy a társadalomra, gazdaságra gyakorolt negatív hatásainak megelőzése, mérséklése érdekében azonnali, hatékony intézkedéseket kell hozni. Ahogy egy tanulmányban szerepel, „, a pénz korrumpáló hatása a demokráciákban a bizalom összeomlásának a jelképe is lehet." (Bell, 1998) Mindezek ellenére sem a hazai, sem a nemzetközi szakirodalomban nem találunk általános elfogadott definíciót a korrupcióra. Egy felfogás szerint a korrupció magában foglalja mind a hatalommal való visszaélésből származó haszonszerzést, mind pedig magát a hatalommal való visszaélést is. (Punch, 1985, 11-12.) Igaz, hogy a korrupció általánosan elfogadott definiálása még mindig nem történt meg, azonban a korrupciós jelenség problémáját már felismerték. (Graham et al., 2013,25) Az egységes fogalom megalkotása nem csak azért nehéz, mert egy erősen strukturált jelenségről beszélünk, hanem azért is, mert a korrupció fogalma nem tárgyszerüsíthető és nem köthető meghatározott cselekvésekhez; a definíció súlypontja időről időre, helyről helyre változhat; a szituációk egyéb különbségeiről nem is beszélve. (Aszalós, 1999, 76-85.)

Amennyiben a korrupciós jelenséggel kívánunk foglalkozni, elengedhetetlen, hogy valamilyen fogalom meghatározás mentén elinduljunk. Jelen tanulmányban a korrupció legveszélyesebb (vagy legalábbis hivatalosan annak nyilvánított) szegmensével, a korrupciós bünözéssel foglalkozom. (Hollán, 2014, 19.)

1 Legfőbb Ellenőrző Intézmények Nemzetközi Szervezete

2 Gazdasági Együttműködés és Fejlesztési Szervezet 
A vizsgálatom során fókuszálok azokra a korrupciós jellegü cselekményekre, amelyek esetében a klasszikus korrupciós büncselekmények megalapozott gyanúja hiányzik, illetve bizonyíthatatlan, de az emellett megvalósuló egyéb büncselekmények gyanúja miatt büntetőeljárás indul. Ennek megfelelöen a fogalom meghatározására Hollán Miklós nézetét használom fel, aki a korrupciós büncselekményeket két csoportba osztotta. Az egyik csoportba az ún. szükségképpen (in abstracto) korrupciós büncselekmények tartoznak, melyek esetében nem csak az elkövetett konkrét cselekmény, hanem a törvényi tényállás is megfelel a korrupció fogalmának. ${ }^{3}$ A másik kategóriába az ún. nem szükségképpen (in concerto) korrupciós büncselekmények tartoznak, ${ }^{4}$ amelyeknél a törvényi tényállás nem felel meg a korrupció fogalmának, de a konkrét elkövetés gyakran igen. A szerző az első csoportba sorolja például a vesztegetés, a vesztegetés elfogadása, a befolyással üzérkedés, a befolyás vásárlása büncselekményeket. Nem szükségképpen korrupciós büncselekményre pedig a hivatali visszaélés, a hütlen kezelés, a versenyt korlátozó megállapodás közbeszerzési és konceszsziós eljárásban deliktumokat említi. (Hollán, 2013, 4.)

A klasszikus korrupció elleni fellépést úgy lehet hatékonyabbá tenni, hogy az adott állam jogalkotói szem előtt tartják azt a tudományos álláspontot, miszerint az ilyen deliktumok akkor ítélhetők el eredményesen, ha mind az államhatalom, mind a törvényhozás, mind pedig a megalkotott törvények rendszere korrupciómentes. (Kocsis, 2000, 17.) Figyelembe kell venni, hogy a korrupciós tranzakciók szereplői meg tudják becsülni a várható kockázatok, költségek mértékét és igyekeznek csökkenteni azokat kapcsolathálók kialakításával, fenntartásával, fejlesztésével annak érdekében, hogy maximalizálják a várható nyereséget. (Szántó et al., 2011, 61-82.) Ez azt jelenti, ha a várható elönyök nagyobbak, akkor az növeli a korrupciós ügyletek bekövetkezésének valószínüségét és gyakoriságát. Ennek megfelelően a korrupció elleni hatékony fellépéshez, megelőzéshez elengedhetetlen a korrupciós büncselekmények esetén a szigorú, konzekvens ítéletek hozatala. A téma vizsgálatát indokolja, hogy a korrupciógyanús esetekben nem mindig indul korrupciós büncselekmény miatt büntetőeljárás, hanem csak az esettel összefüggésben elkövetett egyéb, kisebb súlyú és ezzel együtt kisebb büntetési tételü büncselekmények vonatkozásában történik nyomozás elrendelése és ítélet meghozatala.

3 A Büntető Törvénykönyvről szóló 2012. évi C. törvény (Btk.) XXVII. fejezete: Vesztegetés (Btk. 290. $\S$ ), Vesztegetés elfogadása (Btk. 291. §), Hivatali vesztegetés (Btk. 293. §), Hivatali vesztegetés elfogadása (Btk. 294.§), Vesztegetés bírósági vagy hatósági eljárásban (Btk. 295. §), Vesztegetés elfogadása bírósági vagy hatósági eljárásban (Btk. 296. §), Befolyás vásárlása (Btk. 298. §), Befolyással üzérkedés (Btk. 299. §), Korrupciós büncselekmény feljelentésének elmulasztása (Btk. 300. §).

4 Ilyen lehet például a Hivatali visszaélés (Btk. 305. §), a Hủtlen kezelés (Btk. 376. §), a Versenyt korlátozó megállapodás közbeszerzési és koncessziós eljárásban (Btk. 420. §). 


\section{A korrupciós büncselekmények felderítése, bizonyíthatósága}

Általánosan jellemző a korrupciós büncselekményekre, hogy az elkövetés során legalább két fél áll egymással szemben, egyrészt aki kéri, elfogadja, másrészt, aki adja, ígéri a jogtalan előnyt. (Schubauer, 2013, 375.) A bűncselekmény elkövetésekor $n$ em feltétlenül szükséges, hogy mindkét fél cselekedjen, illetve az sem, hogy mindkettőjük cselekménye korrupciónak minősüljön (Gál, 2013, 183.), ennek ellenére mindkét fél a jogtalanság talaján áll. (Bodrogi, 1983, 324.) A büntető jogalkalmazás során gyorsan bebizonyosodott, hogy a korrupciós büncselekmények bizonyítása rendkívül nehéz. (Lőrinczy, 1987, 93.) Annak okaként, hogy a korrupció a nehezen felderíthetó és nehezen bizonyítható ügyek kategóriájába tartozik, Finszter Géza a következőket nevesíti:

- természetes személy sértettjük nincs;

- a tárgyi bizonyitás lehetöségei igen beszükültek, az elkövetés helyszinének kriminalisztikai értéke alig van;

- a véghezviteli magatartás semmiféle tárgyi nyomot nem hagy a környezetben és sokszor nem különböztethetö meg a mindennapi élet jogszerü cselekményeitöl;

- harmadik személyek számára a deliktumról, hacsak nem részesei a büncselekménynek, pontos és jól reprodukálható ismeretek nem szerezhetök;

- az ilyen cselekmények erkölcsi elutasitása nem egyértelmü." (Finszter, 2011, 75.)

A korrupciós büncselekmények specialitása, hogy a két fél (a jogtalan előnyt adó és az azt elfogadó) együttesen érdekelt a cselekményük leplezésében, a büncselekmény látenciában maradásával. Természetes, hogy a regisztrált büncselekmények száma alacsonyabb a ténylegesen elkövetettektől, de ez a különbség a korrupciós cselekmények esetében nagyon jelentős. A korrupciós büncselekmények esetében előfordul, hogy a büntetőeljárás egy harmadik személy észlelése és bejelentése alapján indul. Ahogy Korinek László megfogalmazta ezzel kapcsolatban: a törvény szeme az állampolgár - és a kriminális korrupciónál a feljelentési hajlandóság mértéke rendkívül alacsony. (Korinek, 2006, 249-257.)

Az elkövetőkkel történő együttmüködés a hatályos büntető kódex értelmében talán még nehezebb lett. Ennek oka, hogy a vesztegetési cselekmények felderítésében a hatóságokkal érdemben együttmüködő elkövetőkkel szemben a korábbi jogszabályban deklarált büntethetőséget megszüntető ok helyett a törvény a büntetés korlátlan enyhítésére vagy mellőzésére ad csak 
lehetőséget. A kodifikáció során erre a változtatásra a Korrupció Elleni Államok Csoportjának (Group of States against Corruption: GRECO) ajánlása miatt került sor, mellyel kapcsolatban Kőhalmi László megjegyzi: e megoldás ugyan megfelel a GRECO ajánlásainak, de nem biztos, hogy kriminálpolitikailag helyeselhető. A GRECO szakértői ugyanis nem értik meg azt a nagyon is pragmatikus szempontot, hogy a nemzetközi szabályozási standardokat szükség esetén országspecifikusan kell alkalmazni. (Kőhalmi, 2015, 23.) Köhalmi rámutat arra, hogy a korrupciós büncselekmények elkövetési gyakorisága, az abban résztvevő személyek köre, valamint az ellenük tevékenykedő bünüldöző szervek feltételrendszere, hatékonysága jelentősen eltér az egyes államokban. A büncselekmények elleni eredményes fellépés érdekében mindenképpen szükséges a megjelölt sajátosságok figyelembevétele a jogszabályok kodifikációja során.

A hatályos büntető kódex megalkotásával megszünt a büntetőjogban és a kriminológiában használt eltérő terminológiának a problémája (Kőhalmi, 2010, p. 294-305), hiszen megszüntette a közélet tisztasága elleni büncselekmények és a nemzetközi közélet tisztasága elleni büncselekmények fejezeteket és létrehozott egy új, egységes fejezetet korrupciós büncselekmények címmel. (Mezei, 2015,95 .) Ezzel pedig egyúttal anyagi büntetőjogi fogalommá emelte a korábban csak a kriminológiában használt terminológiát. (Gál, 2013, 183.)

\section{A rendészeti korrupciós büncselekmények sajátosságai}

A rendészeti korrupció - a korrupciós büncselekmények között - kiemelt társadalmi figyelmet kap, mivel egyik elkövetője egy olyan hatósági személy, akinek épp a társadalom védelmezése lenne a feladata. Ami azt jelenti, hogy a rendészeti korrupció esetében a specifikum az alanyok körére vezethető viszsza. (Kránitz, 1999, 175-177.)

A rendészeti korrupció témakörében „A rendőri korrupció megelözése és viszszaszorítása a magyar rendőrségnél" címủ kutatás keretében a Rendészeti Kutatók Egyesülete 1999-ben végzett kutatást kérdőíves felmérés, interjúkészítés, dokumentumelemzés, illetve sajtófigyelés módszerével. A kutatás eredményeit a 2000. évben megjelent küzdelem a rendőri korrupció ellen címü kiadvány ismerteti. Az azóta eltelt idő alatt sok változás történt a Rendőrség feladatrendszerében, szervezetében, személyi állományában, melyek közül a leglényegesebbek:

- A Rendőrség Alaptörvényben rögzített feladatai megváltoztak a korábbi Alkotmányhoz képest. 
- Megtörtént 2008. január 01. napján a Rendőrség és a Határőrség integrációja, amely jelentős létszámnövekedést, szervezeti és feladatrendszer változást eredményezett.

- Magyarország csatlakozott az Európai Unióhoz, majd a Schengeni Egyezményhez.

- Szinte minden területen új jogszabályok váltották fel az akkori szabályozást, például: új Büntetőtörvénykönyv, új Büntetőeljárásról szóló törvény, új Közigazgatási rendtartásról szóló törvény, új Szabálysértésekről szóló törvény, továbbá a Rendőrségről szóló törvény is számtalan módosításon esett át.

- Megváltozott a bírságolás tevékenység, megjelent az objektív felelősségen alapuló jogsértések elbírálásának gyakorlata, a büntetőpont rendszer, egyes jogsértések közigazgatási hatósági eljárásban történő elbírálása, az útdíj megfizetésének ellenőrzése.

- Megszünt a rendőrök korkedvezményes nyugdíja, majd megváltozott a hivatásos állományú rendőrökre vonatkozó szolgálati törvény, bevezetésre került az új életpálya modell, megjelent a megbízhatósági és kifogástalan életvitel ellenőrzés jogintézménye.

- A rendőrség személyi állományában jelentős fluktuáció következett be.

- Megalakult a Nemzeti Védelmi Szolgálat, amely a rendőrség tekintetében is ellátja a belső bünmegelőzési és bünfelderítési feladatokat.

A Rendőrség munkáját befolyásoló külső környezet is sokat változott az eltelt idő alatt, ezek közül a témához kapcsolódóan az alábbiak emelhetők ki:

- A technikai fejlődés új lehetőségeket ad a korrupció elleni fellépéshez és az eredményes felderítéshez, de a megelőzéshez is.

- Megjelentek a közösségi médiák, az információáramlás felgyorsult.

- Az Európai Uniós, illetve schengeni csatlakozással, valamint a szomszédos országokkal kötött kétoldalú egyezményekkel a nemzetközi bünügyi együttmüködés jelentősen javult, felgyorsult.

- Átalakult az ügyészség szervezetrendszere.

- A rendelkezésre álló releváns adatbázisok köre bővült, elérhetőségük gyorsabb lett.

A változások ellenére természetesen több párhuzam, illetve hasonlóság is tapasztalható a 1999. év és napjaink problémái között:

- A Rendőrség jelenleg is létszámproblémákkal küzd, mivel jelentős az elvándorlás, fluktuáció. A létszámhiány ellentételezésére a rendőri állomány tömeges felvétele jelenti a megoldást. 
- Az 1999. évi kutatás három évvel azt követően történt, hogy a fegyveres szervek hivatásos állományú tagjainak szolgálati viszonyáról szóló 1996. évi XLIII. törvény hatályba lépett. A jelenleg hatályos 2015. évi XLII. törvény a rendvédelmi feladatokat ellátó szervek hivatásos állományának szolgálati jogviszonyáról szolgálati törvény három és fél éve lépett hatályba, melynek alapján az állomány illetményemelése lépcsőzetesen megtörtént. Az új szolgálati törvények hatályba lépését követően, akkor is és most is felmerült, hogy további korrekcióra van szükség, hiszen a rendőri állomány illetménye - különösen a fiatal állomány esetében - jelentősen elmarad a versenyszféra béreitől, így még a pályán tartáshoz sem elegendő. Egyik szolgálati törvény sem eredményezett jelentős előrelépést az állomány elhivatottságának, szervezet iránti lojalitásának területén, ami a korrupció visszaszorításának egyik alappillére lenne.

- A feladatrendszerben, a szervezeti struktúrában, a személyi állományban, külső körülményekben bekövetkezett változások ellenére a rendőri korrupció továbbra is jelen van a szervezetben.

Figyelembe kell venni, hogy a rendészetnek vannak olyan általános vonásai, amelyek a korrupcióra különösen fogékonnyá teszik a közbiztonság és a bünüldözés szolgálatában álló szervezeteket. Ennek alátámasztására a kutatók számos okot sorolnak fel, melyek napjainkban ugyanúgy jellemzőek, mint ezelőtt 20 évvel. Az okok között a kutatók kiemelték a bünüldöző munka és a rendészeti intézkedések sajátosságait, a hatósági erőszak monopolizáltságát, a szakmai etika kialakításának és elfogadtatásának akadályait, a rendészeti ágazat anyagi nehézségeit, a rendvédelmi testületek zártságát, a testületen belüli szolidaritást és azokat a szolgálati helyzeteket, amelyekben érdekazonosság alakulhat ki az aktív és a passzív vesztegető között. (Rendészeti Kutatók Egyesülete, 2000, 15.) A már említett Rendőrség és Határőrség integrációja tovább növelte a korrupciós kockázatokat. A Határőrségnél az állomány veszélyeztetettségét felismerve már a 2000-es évek előtt is elemezték saját szolgálataik egyedi veszélyforrásait és megállapították, hogy a határvédelmi és a határrendészeti feladatokkal kapcsolatban a korrupciós cselekményekkel összefüggésben felmerülhet az embercsempészet, a nemzetközi szervezett bünözés, a kábítószerrel való viszszaélés büncselekmények is. (Grecsó, 1998, 111.)

Ehhez hozzá kell tenni, hogy a rendészeti korrupció bizonyos típusainak esetében a rendőri fél mellett jellemzően külföldi elkövetők állnak, akik átutaznak országunkon. A kutatás óta eltelt 19 évben a hazánkon átutazó külföldiek (többségében korrupcióval fertőzöttebb ország állampolgárainak) száma ugrásszerüen emelkedett, ami növeli az intézkedő rendőrök korrupciós veszélyeztetettségét. Hazánk schengeni csatlakozását követően a külső határokon elköve- 
tett korrupciós cselekmények társadalomra valós veszélyessége még nagyobb hangsúlyt kapott. A belső határokon végzett ellenőrzés megszüntetése a külső határokon dolgozók vonatkozásában az államhatárhoz köthető korrupciós büncselekmények látenciájának növekedését eredményezte.

Egy-egy rendészeti korrupciós esemény - az egyéb korrupciós büncselekmények gazdaságra, társadalomra gyakorolt negatív hatásain túl - a rendészeti szervek megítélésére is káros, mert az állampolgárok állami szervekbe vetett bizalmát megingatja, csökkenti. Emellett a jelenség a rendészeti szerveknél elvárt és az eredményes müködés alapkövetelményének tekinthető rendre, fegyelemre erős negatív hatást gyakorol. Káros következményként ki kell emelni továbbá azt is, hogy a rendészeti korrupció biztonsági deficitet is keletkeztet. A leírtak miatt az ilyen jellegü büncselekmények megelőzése és felderítése prioritást kell, hogy élvezzen.

A rendészeti korrupció azonban nem csak a rendőri tevékenységhez kapcsolódik. A rendőrség ugyan széleskörü feladatrendszerrel rendelkezik, ennek ellenére nem önmagában szemlélendő a korrupciót illetően, hanem a rendészeti szervek együttesen képeznek egy olyan - feladatok és személyi állomány vonatkozásában különös - halmazt, amelynek elemzésével hatékonyabb lehet a korrupció elleni küzdelem, beleértve a bünmegelőzést és a korrupciós büncselekmények minél szélesebb körben történő felderítését (Gáspár, 2014, 3). Jelen tanulmányban ugyanakkor csak a rendőri tevékenységhez kapcsolódó korrupciós jelenségek állnak fókuszban.

Sherman véleménye szerint a rendőrök a korrupcióhoz gyakran fokozatosan jutnak el. A folyamat a kisebb szívesség elfogadásával kezdődik, majd tovább lépnek a korrupció komolyabb formái felé. Álláspontja szerint ebben egyrészt a tapasztalt kollégák iránymutatása, másrészt pedig a felettesek irányában érzett elfogadtatási vágy is szerepet játszik. (Sherman, 1985, 253-265.) Ugyanakkor Bonifacio nézete szerint a kismértékü korrupció révén a rendőrben kialakulhat egy olyan téves meggyőződés, hogy a neki juttatott előnyökben az állampolgárok alázata jelenik meg, ez pedig egyben elvezethet ahhoz a képzethez, hogy a törvények felett áll. Hangsúlyozza azonban, hogy ez a folyamat fordítva is igaz. Azaz az olyan szervezeti kultúra, amely azt sugallja, hogy nem kell a jogszabályokat maradéktalanul betartani, elvezethet a rendőri korrupcióhoz. (Bonifacio, 1991, 39.) Ez a nézőpont felhívja a figyelmet arra, hogy a rendőri szervnél kialakított szervezeti kultúra komoly szerepet játszik abban, hogy a szervezet és az abba integrálódó személyek mennyire tudnak ellenállni a korrupció jelenségének.

A rendőri korrupciós büncselekmények felderítése, bizonyítása a büncselekmények közül talán a legnehezebbek közé tartozik. Ennek okai között - álláspontom szerint - a következőket mindenképpen ki kell emelni: 
- a rendörök között erős összetartozás érzés van, ami miatt egymásra ritkán tesznek terhelö vallomást;

- a rendőri állomány az átlag állampolgárhoz képest jelentősen több szakmai ismerettel rendelkezik a büncselekmények felderítésére, bizonyítására vonatkozóan;

- a rendőrök feladatait meghatározó szabályozás túlzottan összetett és bonyolult, a végrehajtandó folyamatokat nem mindig egyértelmüen határozza meg;

- a rendőri hivatás társadalmi megbecsülésének bár növekvő, de nem elég magas szintje, ami miatt a rendörök nem eléggé büszkék hivatásukra, így nem mindig fektetnek megfelelő hangsúlyt feddhetetlenségük, becsületük megörzésére.

A korrupciós, azon belül is a rendőri korrupciós büncselekmények elkövetői felderítése, büntetőjogi felelősségre vonása érdekében alkalmazkodni kell a specialitásokhoz és ennek megfelelő módszereket kell kiválasztani a hatékony fellépés érdekében. A korrupciós cselekményeknél általában is fontos szempont annak vizsgálata, hogy mennyire váltak részévé az adott intézmény müködésének. Ez alapján a szakemberek megkülönböztetik azokat a korrupciós ügyleteket, amelyek két szereplő között egymástól függetlenül jönnek létre, illetve azokat, amelyek részben egymásra épülve, többszereplős tranzakciókként müködnek. (Inzelt et al., 2014, 17.) Ennek vizsgálata a rendészeti korrupciós cselekményeknél is kiemelt fontosságú. Tekintettel azonban arra, hogy a felderítés, nyomozás az eseti ügyletek esetében is komoly nehézséget jelent, a szervezetten elkövetett deliktumok felderítése, bizonyítása még nagyobb kihívás elé állítja a hatóságokat. Egy kutatás eredményei azt bizonyították, hogy a büntető igazságszolgáltatás jelenleg csupán az úgynevezett kisstílü korrupciós cselekmények kezelésére képes. (Kerezsi et al., 2014b. 32.) Meg kell azonban jegyezni, hogy a meglévő jogi keretek között választ kell keresnünk a probléma megoldására.

A rendőri korrupció elleni fellépésben több szervezet müködik együtt. Ki kell emelni a Központi Nyomozó Főügyészség regionális osztályait, melyek részt vesznek a korrupciós büncselekmények nyomozásában. Emellett szerepet kaptak a megbízhatósági vizsgálat lefolytatásában is, hiszen annak végrehajtására csak ügyészi jóváhagyást követően kerülhet sor, majd a vizsgálat befejezését követően az ügyész a végrehajtás törvényességét is ellenőrzi. A rendészeti korrupció elleni fellépésben fontos szerepe van a Nemzeti Védelmi Szolgálatnak (NVSZ) is, mely önállóan müködő belső bünmegelőzési és bünfelderítési feladatokat ellátó szerv, így kifogástalan életvitel ellenőrzést és megbízhatósági vizsgálatot is folytat. A korrupció megelőzése, feltárása az Országos Rendőr-fö- 
kapitányságnál, valamint a területi és a helyi szerveknél, azok vezetőinél is prioritás. A rendőrségen belül müködő ellenőrzési szolgálatok is külön nevesített feladatokat kaptak a korrupció elleni fellépés érdekében, melynek keretében állományvédelmi ellenőrzéseket hajtanak végre.

A korrupciós cselekmények gyanúja több alkalommal hiába vetődik fel a korrupció ellen küzdő szervezetek dolgozói előtt, azonban a megalapozott gyanú sok esetben nem állapítható meg. A jogalkalmazóknak azonban mindig teljeskörüen kell vizsgálni az adott cselekményeket, hiszen sok esetben bár a korrupciós büncselekmény megalapozott gyanúja nem állapítható meg, a bizonyítása nem lehetséges, azonban más büncselekmények még feltárhatók lehetnek. A rendőri állomány által a korrupciós büncselekmények közül alapvetően a hivatali vesztegetés elfogadása, ${ }^{5}$ valamint a korrupciós büncselekmény feljelentésének elmulasztása ${ }^{6}$ büncselekmények elkövetése merülhet fel. A hivatali vesztegetés elfogadása büncselekmény minősített esete a hivatali kötelességét megszegve fordulat. ${ }^{7}$ Tekintettel arra, hogy a hivatali vesztegetés elfogadása büncselekmény nagyon nehezen bizonyítható, előfordul, hogy csak a hivatali kötelességszegést lehet bizonyítani. Ekkor viszont már nem korrupciós, hanem jelen esetben egy katonai büncselekményről, azaz kötelességszegés szolgálatban büncselekmény ${ }^{8}$ elkövetéséről beszélhetünk. Amennyiben a hivatali vesztegetés elfogadása büncselekmény minősített esete bizonyítható, a katonai büncselekmény már nem konkurál, hanem beolvad a korrupciós büncselekmény minősített esetébe. Előfordul, hogy a korrupciós jellegű cselekmény esetén nemcsak korrupciós büncselekmény, hanem katonai büncselekmény megvalósulásáról sem beszélhetünk, csak fegyelmi felelősségre vonást von maga után a cselekmény. A bizonyítás nehézsége, valamint az átminősítés lehetőségére tekintettel is egyes esetekben előfordul, hogy az egyszerübben, sokszor egyértelmüen bizonyítható katonai büncselekmény elkövetésének bizonyítása érdekében folytatják a nyomozást és emiatt emelnek vádat úgy, hogy a korrupciós büncselekmény bizonytalan kimenetelü nyomozására kisebb energiát fordítanak. Ennek kapcsán kell beszélni a konnexitásról. Előfordul, hogy több büncselekmény elkövetésének megalapozott gyanúja is megállapítható egy adott személy (rendőr) vonatkozásában, melyek közül nem mind tartozik a katonai büntetőeljárás hatálya alá. Ez esetben az általános és a katonai büntetőeljárás versengését idézi elő, hiszen a személyi összefüggés (konnexitás) miatt katonai büntetőeljárásnak van helye olyan büncselekmény esetében is,

5 Btk. 294.§

6 Btk. 300.§

7 Btk. 294.§ (3) aa.) pont

8 Btk. $438 . \S$ 
amelyre egyébként rendes körülmények között a katonai eltérő szabályok alkalmazásának nincs helye (Hautzinger, 2010, p. 139). Tárgyi konnexitás is felmerül, ha több terhelt közül az egyikre a katonai büntetőeljárás hatálya vonatkozik és az eljárás elkülönítése - tekintettel a tényállás szoros összefüggésére - nem lehetséges. (Hautzinger, 2011, 78.) Erre például akkor kerülhet sor, ha a hivatali vesztegetés elfogadása és a civil személy által elkövetett hivatali vesztegetés büncselekmények megalapozott gyanúja miatt folyik a büntetőeljárás.

A Btk. 300. §-ban foglaltak alapján a törvény a hivatali vesztegetés elkövetésénél enyhébben, de mégis szigorúan szankcionálja a hivatalos személyek azon magatartását, ha e minőségükben hitelt érdemlő tudomást szereztek arról, hogy még le nem leplezett vesztegetést vagy vesztegetés elfogadását követtek el, és erről a hatóságnak, mihelyt teheti, nem tesz feljelentést. A törvény szerint vesztegetés feljelentésének elmulasztása miatt az elkövető hivatalos személy hozzátartozója nem büntethetö.

\section{Rendészeti korrupciós büncselekményt felvetö jogesetek elemzése}

Ahhoz, hogy egy jogintézményt vagy egy jogi problémát könnyebben megértsünk, nagy segítséget jelent a gyakorlatban megtörtént esetek megismerése, elemzése. A következőkben két olyan esetet mutatok be, amelyeknél felmerült a hivatali kötelességszegéssel elkövetett hivatali vesztegetés büncselekményének gyanúja, azonban az eljárás eredményeként „csak” az enyhébb büntetési tételü kötelességszegés szolgálatban büncselekmény, vagy fegyelemsértés miatt történt meg a rendőrök elmarasztalása.

\section{Hivatali vesztegetés elfogadása helyett kötelességszegés szolgálatban}

Egy közúti határátkelőhely több szolgálati helyén állományvédelmi ellenörzést hajtottak végre. A kilépő buszforgalmi sávon az ellenőrök azt tapasztalták, hogy a személyek átléptetését kettő fő útlevélkezelő hajtja végre. Az egyik egy útlevelet tart a kezében és helyszíni bírságot szab ki. A másik útlevélkezelő a határforgalom-ellenőrzés vonalán túl összesen hat civil személlyel beszélgetést folytat szerb nyelven, miközben a kezében több útlevél látható. Az útlevélkezelő az ellenőröket meglátva közölte, hogy elkezdi a következő autóbusz fogadását és - kérdés nélkül - elindult a beengedő sorompó felé. A döntése indokolatlan 
és szabálytalan volt, hiszen még az előző busz utasainak maradéktalan átléptetése sem történt meg. Az ellenőr követte az útlevélkezelöt, aki ezt tapasztalva azt mondta, hogy nyitva a sorompó, fel tud jönni a busz és visszafordult a kezelöfülke felé. Ezt követően a fülkéje elött várakozó külföldi állampolgárokat szerb nyelven ki akarta küldeni a terminálból jelezve, hogy a határátléptetésüket végrehajtotta, és egyúttal a hat úti okmányt átadta az egyik személynek. Az ellenőrök felszólították a civileket szerb nyelven, hogy maradjanak a terminálban, tekintettel arra, hogy a buszterminálban szabályszerü határforgalmi ellenőrzés esetén nem lehet egyszerre hat útlevél az útlevélkezelőnél, valamint az okmányokat ismételt személyazonosítást követően az érintett személyeknek személyesen kell visszaadni.

Az eset kivizsgálása során megállapítást nyert, hogy az útlevelek között kettő db 50 Eurós bankjegy volt elhelyezve. A már buszon lévő utasok közül 2 személy határellenőrzési és regisztrációs rendszerbe (a továbbiakban: HERR rendszer) történő bedolgozását, ${ }^{9}$ valamint az útlevelekbe bélyegzőlenyomat elhelyezését elmulasztotta. A hat civil személy közül, akik az útlevélkezelő fülke elött álltak egyikük a soför volt, akinek az útleveleket a rendőr viszszaadta. A további öt személynél, akiknek átléptetését az útlevélkezelő - az ellenőrök megjelenésekor - végre kívánta hajtani, az alábbi problémák voltak megállapíthatók:

1. Az első két személy a schengeni tagállamok területén engedélyezett 180 napon belül 90 napot meg nem haladó tartózkodás időtartamát 90 nappal meghaladták. Velük szemben az elkövetett - 2007. évi II. törvény 6. § (1) bekezdésébe ütköző és a 2012. évi II. törvény 204. § (1) bekezdése szerint minősülő - tiltott határátlépés, úti okmánnyal kapcsolatos szabálysértés miatt intézkedésre nem került sor.

2. A harmadik utas a magánútlevelében elhelyezett bélyegzőlenyomat alapján a schengeni tagállamok területén engedélyezett 180 napon belül 90 napot meg nem haladó tartózkodás időtartamát 27 nappal meghaladta, mivel azonban rendelkezett a német hatóságok által kiállított határátlépési engedély-

9 Meg kell jegyezni, hogy a HERR rendszer különösen fontos a határforgalom ellenőrzés során. Funkciója kettős, mivel egyrészt az útlevélkezelő ezt a rendőrségi rendszert használva ellenőrzi le, hogy az átlépő utas, illetve jármüve, valamint a nála lévő tárgyak nem jelentenek-e veszélyt valamely tagállam közrendjére, belső biztonságára, közegészségügyére vagy nemzetközi kapcsolataira. Ez az ellenőrzés a SIS-ben és a nemzeti adatállományokban tárolt, személyekre, és - amennyiben szükséges - tárgyakra vonatkozó adatoknak és figyelmeztető jelzéseknek, valamint a figyelmeztető jelzés esetén végrehajtandó intézkedésnek a közvetlen lekérdezését foglalja magában. Másrészt az adattárakban való ellenőrzéssel egyidejűleg a HERR rendszer végrehajtja az átlépésre jelentkezö harmadik országbeli állampolgárok adatainak rögzítését, melyet a rendőrség a jogszerü tartózkodás időtartamának ellenőrzése, bünüldözési és bünmegelőzési célból a határátlépéstől számítva öt évig kezel. 
lyel és az abban megjelölt időpontig a schengeni térséget el kívánta hagyni, a kialakított gyakorlat szerint vele szemben a helyszíni bírság mellőzhetö. Ennek ellenére a szabálysértés elkövetése miatt figyelmeztetést kellett volna alkalmazni, és azt dokumentálni.

3. A negyedik utas a schengeni tagállamok területén engedélyezett 180 napon belül 90 napot meg nem haladó tartózkodás időtartamát 90 nappal meghaladta. Az utas rendelkezett a német hatóságok által kiállított határátlépési engedéllyel, de abban bejegyzés arra vonatkozólag, hogy meddig kell elhagynia a schengeni államok területét, nem volt. Ezért vele szemben az elkövetett tiltott határátlépés, úti okmánnyal kapcsolatos szabálysértés miatt 50.000, - Ft helyszíni bírság került kiszabásra.

4. Az ötödik utas a schengeni tagállamok területén engedélyezett 180 napon belül 90 napot meg nem haladó tartózkodás időtartamát 90 nappal meghaladta. Vele szemben az elkövetett tiltott határátlépés, úti okmánnyal kapcsolatos szabálysértés miatt intézkedésre nem került sor. A személy HERR rendszerben történő rögzítését az útlevélkezelő nem hajtotta végre, az útlevélbe a bélyegzőlenyomat elhelyezésre nem került sor. Az útlevélben az adathordozó oldal és a 1. lapoldal között volt elhelyezve a külföldi fizetőeszköz.

A parancsnoki kivizsgálást követően a határrendészeti kirendeltségvezető a mulasztást elkövető útlevélkezelő tekintetében a Btk. 294. § (1) bekezdésébe ütköző és aszerint minősülő hivatali vesztegetés elfogadása büntett elkövetésének megalapozott gyanúja miatt büntetőfeljelentést tett a Központi Nyomozó Főügyészség illetékes Regionális Osztály osztályvezetőjénél.

Emellett a szerb állampolgárokkal szemben pedig a Btk. 293. § (1) bekezdésébe ütköző és a 294. § (2) bekezdés szerint minősülő hivatali vesztegetés büntett elkövetésének megalapozott gyanúja miatt tett büntetőfeljelentést.

Mindezeken túl az útlevélkezelővel szemben a Btk. 438. § (2) bekezdésébe ütköző és a 438. § (3) bekezdés szerint minősülő kötelességszegés szolgálatban büntett elkövetésének megalapozott gyanúja miatt feljelentést tettek.

Az esetet elemezve megállapítható, hogy amennyiben a kivizsgálás alapján indokolt a kötelességszegés szolgálatban büntett miatt feljelentést tenni, akkor a hivatali vesztegetés elfogadás büntett esetében nem a Btk. 294. § (1) bekezdése szerint, hanem a 294. § (2) bekezdés szerint minősülő büntett miatt kellett volna feljelentést tenni.

A kötelességszegés szolgálatban büncselekmény tekintetében pedig nem a 438. § (2) bekezdésébe ütköző és a 438. § (3) bekezdés szerint minősülö, hanem a 438. § (1) bekezdésbe ütközö és a 438. § (2) bekezdés a) pontja szerint minősülő büntett miatt lehetett volna feljelentést tenni. 
A feljelentést követően az ügyész bíróság elé állításban vizsgálta az ügyet és emelt vádat az illetékes Törvényszéken. A nyomozás során arra az eredményre jutott az ügyész, hogy kizárólag a Btk. 438. § (1) bekezdésbe ütköző és a 438. $\S$ (2) bekezdés a) szerint minősülő folytatólagosan elkövetett kötelességszegés szolgálatban büncselekményt találta megalapozottnak, és emiatt emelt vádat. A korrupciós jellegủ cselekménnyel nem foglalkoztak, az útlevélben elhelyezett készpénznek nem tulajdonítottak jelentőséget. Az érintett személy vallomása szerint csak benne felejtette a pénzt az okmányban, ez alapján a hivatali vesztegetés vagy a hivatali vesztegetés elfogadása büncselekményeket az ügyészség nem látta bizonyíthatónak.

A bíróság - a vádhoz kötöttség kihangsúlyozása mellett - három rendbeli kötelességszegés szolgálatban büntett elkövetése miatt ítélte el az útlevélkezelöt annak ellenére, hogy nem három, hanem összesen hat személy határátléptetése során nem hajtotta végre a szükséges intézkedéseket. A korrupciós jellegü cselekmény nem került értékelésre a nyomozási-, ennek megfelelően pedig a bírói szakban sem.

\section{Hivatali vesztegetés elfogadása helyett fegyelemsértés}

Egy közúti határátkelőhely belépő buszforgalmi sávján szolgálatot teljesítők vonatkozásában állományvédelmi ellenőrzést hajtottak végre. Az ellenőrök érkezésükkor látták, hogy egy útlevélkezelő a sofőrrel együtt, kicsit távolabb pedig egy másik útlevélkezelő sétál a határforgalmi ellenőrzési vonal irányába. Az ellenőröket meglátva az útlevélkezelők sietősen folytatták útjukat. Fel kellett szólítani őket, hogy várják meg az ellenőrző elöljárókat. Ezt követően megállapítást nyert, hogy a sorompók nem voltak lezárva, a terminálban a fülkék őrizet nélkül, nyitott állapotban voltak. Az útlevélkezelők elhagyták szolgálati helyüket. A soförrel együtt haladó útlevélkezelő kezében lévő útlevelekben 10 Euró készpénz, míg a másik útlevélkezelő egyenruhájának bal oldali zsebéből többszöri felszólítást követően 175 Eurót (több kisebb részekben összegyürve) és $16.500,-\mathrm{Ft}$ készpénzt adott elő. Az első útlevélkezelő elmondása szerint még nem hajtotta végre az útlevelek ellenőrzését annak ellenére, hogy a vonatkozó szabályok szerint az okmányok elvételekor személyazonosítást kell végrehajtani. Ezt a feladatot azért sem hajthatta végre, mivel egy soförtől vette át a két személy útlevelét. A másik útlevélkezelő elmondása szerint a pénzt a busz mellett találta. Ennek ellentmondott, hogy a pénz száraz volt, az időjárás pedig esős volt, valamint az is, hogy a pénz találását sem a járőrparancsnoknak, sem pedig az ellenőröknek nem jelentette. 
A parancsnoki kivizsgálást követően a kirendeltség vezetője az útlevélkezelővel szemben, akinél a 175 Euró készpénz előtalálásra került, a Btk. 294. § (1) bekezdésébe ütköző és aszerint minősülő hivatali vesztegetés elfogadása büntette miatt feljelentést tett.

A nyomozás során az ügyész a hivatali vesztegetés elfogadása büncselekmény elkövetését nem találta bizonyíthatónak, így a nyomozást a Be. 190. § (1) bekezdés b) pontjában foglaltak szerint megszüntette.

Ezen túlmenően egy rendbeli, a Btk. 438. § (1) bekezdésébe ütköző és aszerint minősülő szolgálatban kötelességszegés vétsége miatt szintén feljelentésre került sor, mivel az útlevélkezelő elhagyta szolgálati helyét.

A kötelességszegés szolgálatban büncselekmény nyomozását is az ügyész a Be. 190. § (1) bekezdés b) pontja alapján megszüntette.

Továbbá még egy rendbeli a Btk. 438. (1) bekezdésébe ütköző és aszerint minősülő szolgálatban kötelességszegés vétsége miatt is feljelentést tett a parancsnok, mivel az útlevélkezelő - az állítása szerint - a talált pénzt nem jelentette haladéktalanul az elöljárójának és az engedélyezettet (összesen 10.000, - Ft vagy annak megfelelő értékü külföldi fizetőeszköz) jelentősen meghaladó készpénzt tartott magánál.

E tekintetben az ügyész szintén a nyomozás megszüntetéséről határozott, azonban ez esetben a Be. 190. § (1) bekezdés a) pontja szerint és emellett fegyelmi eljárást kezdeményezett.

Az esetet elemezve meg kell állapítani, hogy a nyomozás során az ellenőrök kihallgatására nem került sor, továbbá a határátkelőhely térfigyelő kamerarendszerének valamennyi felvétele nem került értékelésre, hiszen a felvételek alapján egyértelmüen látható, hogy mindkét útlevélkezelö hosszabb időre elhagyja a terminált, bemegy a fóépületbe. Ezt követően a kérdéses útlevélkezelő onnan tér vissza a terminálba. Míg a másik útlevélkezelö az egyik személyforgalmi sávon lévő fülkéhez megy - ahol egy másik rendőr dolgozott - és beül a fülkébe. Mindeközben a határátlépésre jelentkező busz egyik soförje keresi őket először a terminálban, aztán pedig a fóépület ügyfélvárójában, de ez nem vezet eredményre.

Továbbá meg kell jegyezni, hogy az útlevélkezelő a terminálból a fóépületbe ment, ahol a szolgálatparancsnok teljesíti szolgálati feladatait, de nem jelentette részére, hogy pénzt talált. Ezt követően látszik a felvételeken, ahogy elhaladt a határátkelőhelyen álló busz mellett, de nem hajolt le, hogy bármit felvegyen a földröl. Ebből az valószínüsíthető, hogy a pénz már akkor a birtokában lehetett, amikor a szolgálatparancsnok szolgálati helyéhez ment, mégsem tett eleget jelentési kötelességének.

Az elemzett esetben a korrupcióra utaló adat, valamint az ezzel összefüggő jelentési kötelezettség elmaradása kizárólag fegyelmi felelősségre vonást eredményezett. 


\section{Összegzés}

A korrupció elleni fellépés jövőbeli irányait vizsgálva célszerü Hollán Miklós két alapvetéséből kiindulni. Az egyik szerint a korrupciós cselekményeket - hasonlóan sok más kedvezőtlen társadalmi jelenséghez (pl. a bünözéshez) könnyebb és olcsóbb megelőzni, mint jóvátenni az azok által okozott károkat. Míg a másik alaptétel az, hogy ha lenne lehetöség a korrupció teljes megszüntetésére, az akkor sem lenne célravezető. A korrupció elleni fellépést ugyanis úgy kell megtervezni, hogy annak költségei nem haladhatják meg az annak segítségével kiküszöbölhető hátrányokat. (Hollán, 2013b, 2.)

Ezeket az alapvetéseket figyelembe véve kell lépéseket tenni a korrupció megelőzése, mérséklése érdekében. Ennek egyik fontos eszköze a korrupciós cselekmények felderítési eredményességének növelése, és a felderített esetek kapcsán súlyosabb ítéletek meghozatala, amelyek komoly visszatartó erőt jelentenek. Fel kell hívni a figyelmet arra, hogy az esetet teljeskörüen elemezni kell, a minősítő körülményeket lehetőség szerint fel kell tárni, a feljelentéseket kellő körültekintéssel kell megtenni.

A vesztegetési ügyek felderítésének nehézségei a büncselekmény természetéből adódnak, így azokkal hosszútávon számolni kell. (Finszter, 2011, 96.) Ennek ellenére a jogalkalmazók nem elégedhetnek meg egy korrupciós jellegü esemény vizsgálatakor azzal, hogy a hivatali vesztegetés elfogadása büncselekmény minősített esete helyett egy enyhébb súlyú katonai büncselekmény miatt az érintett személy büntetőjogi felelősségét sikerül megállapítani, vagy fegyelemsértés miatt megtörténik a elmarasztalása. Ez nemcsak azért lényeges, hogy az állam érvényesíteni tudja az elkövetett cselekményért a büntetőjogi igényét, hanem azért is, mert ellenkező esetben a büntetés prevenciós hatása nem érvényesül teljeskörüen sem az elkövető, sem a társadalom vonatkozásában. Ami azt jelenti, hogy az elkövetett cselekmény enyhébb megítélése és az ehhez kapcsolódó elmarasztalás alkalmazása adott esetben még bátoríthatja is a potenciális bünelkövetőket. A jogszabályok adta lehetőségeket ki kell használni és mindent meg kell tenni annak érdekében, hogy a tényállás tisztázásra kerüljön és a ténylegesen elkövetett cselekményért feleljen az érintett személy.

\section{Felhasznált irodalom}

Aszalós, J. (1999): A korrupcióról. Iskolakultúra, 9. 76-85.

Báger, G. (2012): Korrupció: büntetés, integritás, kompetencia. Budapest: Akadémiai Kiadó 
Bell, D. (1993): The Old War. The New Republic, 2.

Bodrogi, K. (1981): A közélet tisztasága elleni büncselekmények = Magyar Büntetőjog. Budapest: BM Könyvkiadó

Bonifacio, P. (1991): The Psychological Effects of Police Work. A Psychodynamic Approach, Plenum Press

Finszter, G. (2011): A korrupció nyomozása. Belügyi Szemle, 59. 75.

Gál, I. L. (2013): A korrupciós büncselekmények = Új Btk. kommentár. Budapest: Nemzeti Közszolgálati és Tankönyvkiadó Zrt

Gáspár, M. (2014): A rendészeti korrupció aktuális kérdései. Budapest: Rendészeti Kutatóműhely

Graham, B., David, W., Chris, L, Hakkyong, K. (2013): Preventing Corruption - Investigation, Enforcement and Governance. Hampshire: Crime Prevention and Security Management

Grecsó, I. - Léhner, Gy. (1998): Hivatásos határőrizet-terjedő korrupció. Belügyi Szemle, 10. 111.

Hautzinger, Z. (2010): A katonai büntetőjog rendszertana. Pécs: AndAnn Oktatási és Szolgáltató $\mathrm{Kft}$

Hautzinger, Z. (2011): A katonai büntetöeljárás fejlesztési irányai. Budapest: Dialóg Campus Kiadó

Hollán, M. (2013): Korrupciós büncselekmények az új magyar Büntetö Törvénykönyvben. http:// www.korrupciomegelozes.kormany.hu/download/7/bd/80000/Holl\%C3\%A1n_Mikl\%C3\%B3s_ HU.pdf

Hollán, M. (2014): Korrupciós büncselekmények az új büntető kódexben. Budapest: HVGORAC Lap- és Könyvkiadó Kft

Kerezsi, K. - Inzelt, É. - Lévay, M. (2014): Korrupciós büncselekmények a büntető igazságszolgáltatás tükrében - Milyen cselekményeket rejtenek a jogerösen elitéltek aktái? Kriminológiai Tanulmányok 51.

Kocsis, T. (2000): Az Altern-csoport a korrupcióról. Kovász, 4. 5-24.

Korinek, L. (2006): A bünözés visszatükrözödése. Látens bünözés, bünözésábrázolás, félelem a bünözéstől. Budapest: Complex Kiadó Jogi és Üzleti Tartalomszolgáltató Kft

Kőhalmi, L. (2015): A korrupció. Pécs: Pécsi Tudományegyetem, Állam-és Jogtudományi Kar Gazdasági Büntetőjogi Kutatóintézet

Köhalmi, L. (2010): Büntetőjogi eszközök a politikai korrupció elleni küzdelemben. Politika és korrupció: A törvényesség és törvénytelenség határai. Pécs: Pécsi Tudományegyetem Állam-és Jogtudományi Kar, Pécs-Baranyai Értelmiségi Egyesület

Kránitz, M. (1986): A korrupció. Budapest: BM Könyvkiadó

Kránitz, M. (1999): A korrupció. Kriminológiai ismeretek. Budapest: Corvina Kiadó

Lörinczy, Gy. (1987): A korrupciós büncselekmények bizonyitásáról. Belügyi Szemle, 2. 93-95.

Mezei, K. (2015): Néhány észrevétel a korrupciós deliktumok hatályos szabályozásával kapcsolatosan, Büntetöjogi Szemle, 3. 95.

Punch, M. (1985): Conduct Unbecoming: The Social Construction of Police Deviance and Control, London: Tavistock Publications 
Shermann, L. A. W. (1985): Becoming bent: Moral careers of corrupt policemen. In: Elliston, F. - Feldberg, M. (1985): Moral Issues in Police Work. Maryland: Rowman \& Allanheld Schubauer, L. (2013): A korrupciós bűncselekmények. In: Blaskó, B. - Miklós, I. - Pallagi, A. - Polt, P. - Schubauer, L.: Büntetőjog Különös Rész I. Budapest: Rejtjel Kiadó

Szántó, Z. - Tóth, I. J. - Varga, Sz. (2011): A korrupció társadalmi és intézményi szerkezete. Szociológiai Szemle, 3. 61-82. 